\title{
CONSUMERS' ENVIRONMENTAL MANAGEMENT OF WASTE ANALYSIS OF THE FORMER YUGOSLAVIAN REPUBLICS
}

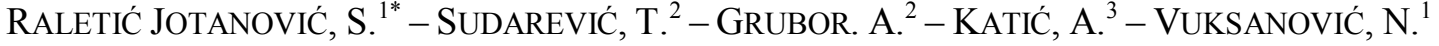 \\ ${ }^{I}$ Professional College of Management and Business Communications \\ Mitropolita Stratimirovića 110, Sremski Karlovci, Republic of Serbia \\ ${ }^{2}$ Faculty of Economics, University of Novi Sad \\ Segedinski put 9-11, 24000 Subotica, Republic of Serbia \\ ${ }^{3}$ Faculty of Technical Sciences, University of Novi Sad \\ Trg Dositeja Obradovića, 21000 Novi Sad, Republic of Serbia \\ *Corresponding author \\ e-mail: raletic.sasa84@gmail.com
}

(Received $8^{\text {th }}$ Dec 2018; accepted 10 $0^{\text {th }}$ Apr 2019)

\begin{abstract}
The aim of this study is to compare environmental management of waste between consumers of the former Yugoslavian republics. The starting points are H1: there are differences in environmental management of waste between consumers from the former Yugoslavian republics and H2: there are demographic differences in consumers' environmental management of waste between consumers from the former Yugoslavian republics. The survey was conducted on a sample of 1550 respondents from all the former Yugoslavian republics. The obtained results show that there are differences between consumers from Macedonia and all other former Yugoslavian republics as well as between Montenegro and Serbia, Croatia and Slovenia. Also, differences were noticed between consumers' environmental management of various types of waste. At the same time, results indicate that there are no differences in gender but differences in age, degree of education and monthly income by households exist related to environmental management of waste between consumers from former Yugoslavian republics. Through adequate implementation of obtained results, consumers' environmental management of waste may become a powerful tool of environmental protection, because it would contribute to the increase of environmentally responsible behavior of consumers in the region of former Yugoslavian republics as well as on a global basis.
\end{abstract}

Keywords: consumers, waste disposal, ecological, former Yugoslavian republics, cross-cultural

\section{Introduction}

Present level of consumer waste management is worrying level. This is indicated, among others, by facts related to plastic and electronic waste:

- $90 \%$ of waste floating in the oceans is plastic waste (http1://www.theworldcounts.com/stories/Plastic-Waste-Facts=).

- In the North Pacific Ocean there is 6 times more plastic waste than plankton, causing the death of the living world in the ocean (http1://www.theworldcounts.com/stories/Plastic-Waste-Facts=).

- Plastics are made from toxic materials such as benzene and vinyl hydrochloride, and these chemicals are known to cause cancer (http1://www.theworldcounts.com/stories/Plastic-Waste-Facts=).

- We generate about 40 million tons of electronic waste worldwide every year (http1://www.theworldcounts.com/stories/Plastic-Waste-Facts=).

- E-waste contains hundreds of substances, many of which are toxic. This includes mercury, lead, arsenic, cadmium, selenium, and chromium (http2://www.theworldcounts.com/stories/Electronic-Waste-Facts). 
- $70 \%$ of total toxic waste is e-waste (http2://www.theworldcounts.com/stories/Electronic-Waste-Facts).

This suggests that the adequate waste management by consumers, in a way that would not degrade the environment, is a necessity and a global problem today.

Disposal of waste in an ecological way implies the disposal of products that have expired or are defective and the disposal of product packaging after consuming the products at designated locations, in adequate containers and warehouses, and in an adequate manner.

Since consumers' environmental management of waste is a global problem, crosscultural studies of consumers' habits regarding management of waste are excellent tools to provide information on the consumers' environmental management of waste and the way in which it may be improved at the regional level.

However, there are not enough cross-cultural studies on the topic of consumers' environmental management of waste, but only those comparing consumers from two countries: French - USA (United States of America) (Arbuthnot and Lingg, 1975), Belgium - Poland (Roozen and Pelsmacker, 2000), Switzerland - India (SinhaKhetriwala et al., 2005), Norway - USA (Kipperberg, 2007) and USA - China (Xu et al., 2014).

Therefore the authors have concluded that there is no relevant cross-cultural research paper which analyses consumers' environmental management of waste between consumers from former Yugoslavian republics: the Republic of Serbia (Serbia), the Republic of Croatia (Croatia), the Republic of Slovenia (Slovenia), the Former Yugoslav Republic of Macedonia (FYR Macedonia), the Federation of Bosnia and Herzegovina (Bosnia and Herzegovina) and Republic of Montenegro (Montenegro).

There are two cross-cultural studies conducted on a sample of all six of the former Yugoslavian republics regarding environmentally responsible purchasing (Raletić Jotanović et al., 2016) and environmentally responsible consumption (Raletić Jotanović et al., 2017).

The aim of this study is to compare environmental management of waste between consumers from former Yugoslavian republics. The former Yugoslavian republics are selected for comparison because: a) they had 73 years of shared history which certainly influenced similarities in consumer behavior, and b) today all the former Yugoslavian republics are independent countries with different macro, structural, demographic, socio-economic, and other characteristics (State Statistical Office of Macedonia, 2018; Institute for Statistics of Serbia, 2018; Statistical Office of the Slovenia, 2018; Statistical Office of the Montenegro, 2018; Croatian Bureau of Statistics, 2018; Federal Office of Statistics of Bosnia and Herzegovina, 2018). According to the authors' knowledge this will be the first cross-cultural study of the former Yugoslavian republics regarding consumers' environmental management of waste.

\section{Environmental management of waste between consumers from different countries}

Consumers' environmental management of waste is different in different countries, according to the results of previous empirical comparative cross-cultural researches: (Arbuthnot and Lingg, 1975; Roozen and Pelsmacker, 2000; Sinha-Khetriwala et al., 2005; Kipperberg, 2007; Xu et al., 2014). Minimal differences were observed in consumers' environmental management of waste between in France and USA (Arbuthnot and Lingg, 1975). Belgian consumers manage their waste more environmentally than Polish ones (Roozen and Pelsmacker, 2000). The consumers from 
the Switzerland manage their e-waste (computers, television sets, microwave ovens, etc.) more environmentally than consumers from India (Sinha-Khetriwala et al., 2005). Environmental management of waste sometimes is better with consumers from Norway and sometimes with consumers from the USA, depending on the type of waste (Kipperberg, 2007). The consumers from the USA are more prone to dispose clothing and footwear at environmental way (using and buying second-hand clothing and footwear) than consumers from China (Xu et al., 2014). All these differences may be explained by differences in level of consciousness, knowledge and attitude towards environment in consumers from different countries (Arbuthnot and Lingg, 1975; Roozen and Pelsmacker, 2000; Sinha-Khetriwala et al., 2005; Kipperberg, 2007; Xu et al., 2014)

According to the results of previous studies, numerous macro factors have affected environmentally responsible consumer choice which also includes consumers' environmental management of waste (Dolan, 2002; Schaefer and Crane, 2005; Thøgersen, 2005; Assadourian, 2010; Marx et al., 2010). In other words, macro factors may be the basis for differences in environmental management of waste between consumers from various countries. Factors that could affect these differences between the former Yugoslavian countries are shown in Table 1.

Table 1. Macro factors of former Yugoslavian countries. (Sources: WEF, 2018 pp. 499, 519, 363, 109, 403, 179; WEF, 2016 pp. 122, 156, 244, 266, 314, 322; WEF, 2014 p. 68)

\begin{tabular}{|c|c|c|c|c|c|c|}
\hline Factors Country & 竞 & $\begin{array}{l}\text { क्ञ } \\
\text { के } \\
\text { के }\end{array}$ & 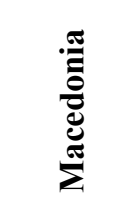 & 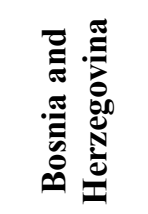 & 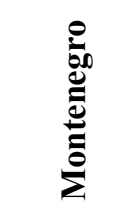 & שֶّ \\
\hline $\begin{array}{l}\text { GDP per capita } \\
\text { (US\$) }\end{array}$ & $5,899.0^{1}$ & $20,732.5^{2}$ & $5,474.4^{3}$ & $5,149.0^{4}$ & $7,647.0^{5}$ & $13,138.3^{6}$ \\
\hline $\begin{array}{l}\text { Environmental } \\
\text { footprint }\end{array}$ & $2.9^{1}$ & $4.7^{2}$ & $3.1^{3}$ & $3.3^{4}$ & $3.4^{5}$ & $3.6^{6}$ \\
\hline $\begin{array}{l}\text { Quality of } \\
\text { education }\end{array}$ & $3.55^{7}$ & $4.6^{8}$ & $3.85^{9}$ & $3.15^{10}$ & $3.92^{11}$ & $3.7^{12}$ \\
\hline $\begin{array}{c}\text { Sophistication of } \\
\text { business }\end{array}$ & $3.00^{7}$ & $4.03^{8}$ & $3.6^{9}$ & $3.23^{10}$ & $3.46^{11}$ & $3.53^{12}$ \\
\hline $\begin{array}{l}\text { Environmental } \\
\text { sustainability }\end{array}$ & $3.86 \rightarrow$ & $4.78 \pi$ & ע ע 3.66 & & $4.38 \rightarrow$ & $4.21 \rightarrow$ \\
\hline
\end{tabular}

The World Economic Forum does not publish each year all the parameters for ranking countries listed Table 1, so, for example, environmental sustainability as a factor was last measured and published in the Global Competitive Report for 20142015.

Table 1 is obviously missing values for environmental sustainability for Bosnia and Herzegovina. Also, data in Table 1 show that Slovenia had the highest values for all factors. Serbia had the lowest values for environmental footprint and sophisticated business, Bosnia and Herzegovina had the lowest values of GDP (gross domestic product) per capita and quality of education, while Macedonia had the lowest value of environmental sustainability.

Considering the results of earlier cross-cultural researches (Arbuthnot and Lingg, 1975; Roozen and Pelsmacker, 2000; Sinha-Khetriwala etal., 2005; Kipperberg, 2007; 
$\mathrm{Xu}$ et al., 2014) and macro and structural factors of former Yugoslavian republics shown in the Table 1, it can be assumed that:

H1: There are differences in consumers' environmental management of waste for different former Yugoslavian republics.

Relationships between consumers' environmental management of waste and demographic characteristics of consumers: gender, age, professional qualifications and monthly income by household, were analyzed in numerous studies conducted in different countries (Samdahland Robertson, 1989; Granzin and Olsen, 1991; Shamdasaniet al., 1993; Chan, 2001; Gilg et al., 2005; Jain and Kaur, 2006; Tilikidou and Delistavrou, 2008; Abeliotis et al., 2010; De Paço and Raposo, 2010; Pedrini and Ferri, 2014; Pinto et al., 2014; Pagiaslis and Krontalis, 2014; Aschemann-Witzel et al., 2017; Paço andLavrador, 2017; Pérez-Belis et al., 2017; Zhanget al., 2018; Scherer et al., 2018; Savchenkoet al., 2019; Talia et al., 2019). These relationships are shown in the Table $2 a-d$.

Table 2a. The relationships between consumers' environmental management of waste and the gender of consumers in different countries

\begin{tabular}{c|c|c|c}
\hline Country & Women and men are equal & $\begin{array}{c}\text { Women are more active } \\
\text { than men }\end{array}$ & $\begin{array}{c}\text { Man are more active than } \\
\text { women }\end{array}$ \\
\hline USA & Shamdasani et al., 1993 & Granzin and Olsen, 1991 & Savchenko et al., 2019 \\
\hline Singapore & Gilg et al., 2005 & & \\
\hline UK & $\begin{array}{c}\text { Tilikidou and Delistavrou, } \\
\text { 2008; Abeliotis et al., 2010 }\end{array}$ & & \\
\hline Greece & $\begin{array}{c}\text { De Paço and Raposo, 2010; } \\
\text { Paço and Lavrador, 2017 }\end{array}$ & & \\
\hline Italy & $\begin{array}{c}\text { Pedrini and Ferri, 2014; } \\
\text { Talia et al., 2019 }\end{array}$ & & \\
\hline Spain & & Pérez-Belis et al., 2017 & \\
\hline India & Scherer et al., 2018 & Pain and Kaur, 2006 & \\
\hline Germany & Pinto et al., 2014 & \\
\hline
\end{tabular}

Table $2 \boldsymbol{b}$. The relationships between consumers' environmental management of waste and the age of consumers in different countries

\begin{tabular}{|c|c|c|c|}
\hline Country & $\begin{array}{c}\text { Older consumers are more } \\
\text { active }\end{array}$ & $\begin{array}{c}\text { Younger consumers are } \\
\text { more active }\end{array}$ & Age does not affect \\
\hline USA & Savchenko et al., 2019 & Granzin and Olsen, 1991 & \\
\hline Singapore & & & Shamdasani et al., 1993 \\
\hline UK & $\begin{array}{l}\text { Samdahl and Robertson, } \\
\text { 1989; Gilg et al., } 2005\end{array}$ & & \\
\hline China & Chan, 1999 & & \\
\hline Portugal & De Paço and Raposo, 2010 & & \\
\hline Italy & & Talia et al., 2019 & \\
\hline Spanish & Pérez-Beliset al., 2017 & & \\
\hline Denmark & $\begin{array}{l}\text { Aschemann-Witzel et al., } \\
2017\end{array}$ & & \\
\hline Germany & $\begin{array}{l}\text { Pagiaslis and Krontalis, } \\
2014\end{array}$ & & $\begin{array}{c}\text { Pinto et al., 2014; Scherer et } \\
\text { al., } 2018\end{array}$ \\
\hline
\end{tabular}


Table 2c. The relationships between consumers' environmental management of waste and the professional qualifications of consumers in different countries

\begin{tabular}{c|c|c|c}
\hline Country & $\begin{array}{c}\text { Educated consumers are } \\
\text { more active }\end{array}$ & $\begin{array}{c}\text { Less educated consumers } \\
\text { are more active }\end{array}$ & $\begin{array}{c}\text { Professional qualifications } \\
\text { does not affect }\end{array}$ \\
\hline USA & Granzin and Olsen, 1991 & Arbuthnot and Lingg, 1975 & \\
\hline Singapore & & & Shamdasani et al., 1993 \\
\hline UK & Chan, 1999 & $\begin{array}{c}\text { Samdahl and Robertson, } \\
1989\end{array}$ & \\
\hline China & $\begin{array}{c}\text { Tilikidou and } \\
\text { Delistavrou, 2008; } \\
\text { Abeliotis et al., 2010 }\end{array}$ & & \\
\hline Portugal & $\begin{array}{c}\text { De Paço and Raposo, } \\
2010\end{array}$ & & \\
\hline Italy & $\begin{array}{c}\text { Pedrini and Ferri, 2014; } \\
\text { Talia et al., 2019 }\end{array}$ & & \\
\hline India & Jain and Kaur, 2006 & & \\
\hline Denmark & $\begin{array}{c}\text { Aschemann-Witzel et al., } \\
2017\end{array}$ & & \multirow{2}{*}{ Scherer et al., 2018 } \\
\hline Germany & $\begin{array}{c}\text { Pagiaslis and Krontalis, } \\
\text { 2014; Pinto et al., 2014 }\end{array}$ & & \\
\hline
\end{tabular}

Table $2 d$. The relationships between consumers' environmental management of waste and the monthly income of consumers in different countries

\begin{tabular}{|c|c|c|c|}
\hline Country & $\begin{array}{l}\text { Consumers who have higher } \\
\text { incomes are more active }\end{array}$ & $\begin{array}{l}\text { Consumers who have lower } \\
\text { incomes are more active }\end{array}$ & $\begin{array}{l}\text { Monthly earnings } \\
\text { does not affect }\end{array}$ \\
\hline USA & Granzin and Olsen, 1991 & & \\
\hline Singapore & & & Shamdasani et al., 1993 \\
\hline UK & & Samdahl and Robertson, 1989 & \\
\hline China & Chan, 1999 & Zhang et al., 2018 & \\
\hline Portugal & De Paço and Raposo, 2010 & & \\
\hline Italy & $\begin{array}{l}\text { Pedrini and Ferri, 2014; Talia et } \\
\text { al., } 2019\end{array}$ & & \\
\hline India & Jain and Kaur, 2006 & & \\
\hline Greece & $\begin{array}{c}\text { Tilikidou and Delistavrou, 2008; } \\
\text { Abeliotis et al., } 2010\end{array}$ & & \\
\hline Germany & $\begin{array}{l}\text { Pagiaslis and Krontalis, 2014; } \\
\text { Pinto et al., } 2014\end{array}$ & & Scherer et al., 2018 \\
\hline Denmark & Aschemann-Witzel et al., 2017 & & \\
\hline
\end{tabular}

Given the results of previously conducted research from Table 2, the basic assumption is that:

H2: There are differences in demographic characteristics of consumers related to consumers' environmental management of waste from different former Yugoslavian republics. 


\section{Materials and methods}

\section{Sample}

The study included 1,550 respondents from six former Yugoslavian republics: $17.81 \%$ (276) participants from Serbia, 16.13\% (250) participants from Croatia, $17.10 \%$ (265) participants from Bosnia and Herzegovina, 16.13\% (250) participants from Montenegro, 16.32\% (253) participants from Macedonia and 16.51\% (256) participants from Slovenia (Table 3).

Table 3. Sample composition. (Source: authors' data)

\begin{tabular}{|c|c|c|c|c|c|c|c|c|}
\hline 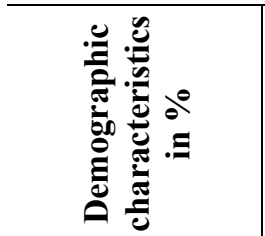 & & 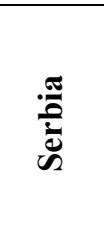 & 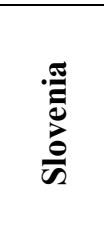 & 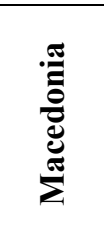 & 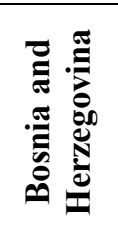 & 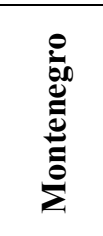 & 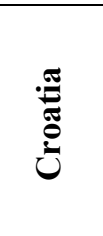 & $\frac{\partial}{0}$ \\
\hline \multirow{2}{*}{ Gender } & Male & 41.30 & 27.34 & 36.76 & 41.89 & 43.6 & 31.2 & 37.01 \\
\hline & Female & 58.70 & 72.66 & 63.24 & 58.11 & 56.4 & 68.8 & 62.90 \\
\hline \multirow{6}{*}{ Age } & $18-30$ & 42.75 & 32.81 & 41.50 & 55.09 & 78.8 & 54.8 & 50.76 \\
\hline & $31-40$ & 31.16 & 34.77 & 26.88 & 24.91 & 13.6 & 19.2 & 25.23 \\
\hline & $41-50$ & 7.97 & 21.48 & 11.07 & 13.58 & 6.40 & 13.6 & 12.52 \\
\hline & $51-60$ & 11.59 & 8.60 & 9.49 & 6.04 & 0.8 & 9.6 & 7.68 \\
\hline & $61-70$ & 5.07 & 1.95 & 5.53 & 0.38 & 0.4 & 2.4 & 2.65 \\
\hline & 71-80 & 0.72 & 0 & 3.16 & 0.00 & 0 & 0.4 & $<1$ \\
\hline \multirow{4}{*}{$\begin{array}{l}\text { Degree of } \\
\text { education }\end{array}$} & Primary school & 1.81 & 0.78 & 2.37 & 0.00 & 0 & 0.8 & $<1$ \\
\hline & High school & 45.65 & 17.19 & 41.11 & 50.57 & 49.20 & 48.40 & 39.81 \\
\hline & College, university & 33.70 & 59.77 & 27.27 & 31.32 & 35.6 & 38 & 39.81 \\
\hline & $\mathrm{MSc} / \mathrm{PhD}$ & 18.12 & 21.88 & 27.67 & 18.11 & 15.20 & 12.8 & 19.61 \\
\hline \multirow{3}{*}{$\begin{array}{l}\text { Monthly income } \\
\text { by household }\end{array}$} & Below average & 25.36 & 19.53 & 11.07 & 7.92 & 22.8 & 16.8 & 33.68 \\
\hline & Average & 40.22 & 47.27 & 57.70 & 72.83 & 47.00 & 69.6 & 48.90 \\
\hline & Above average & 34.06 & 32.81 & 31.23 & 19.25 & 30.2 & 13.6 & 17.30 \\
\hline Total & & 276 & 256 & 253 & 265 & 250 & 250 & \\
\hline$\%$ & & 17.81 & 16.51 & 16.32 & 17.10 & 16.13 & 16.13 & 100 \\
\hline
\end{tabular}

When analyzing sample structure regarding the gender, that there is twice as much women than men (62.90\% and $37.01 \%$, respectively) (Table 3).

When considering the age structure of the sample, respondents between 18 and years of age make up the majority of the sample, i.e., $50.76 \%$ of the sample, while respondents between 71 and 80 are the least represented in the sample with $<1 \%$ (Table 3). The second biggest category in the sample, according to age, is composed of respondents aged 31 to 40 with $25.23 \%$ of the sample, followed by respondents aged 41 to 50 years with $12.52 \%$ of the sample, then respondents between the age of 51 and 60 which make up $7.68 \%$ of the sample, while subjects between 61 and 70 years make up $2.65 \%$ of the sample. Seven of the respondents did not answer the question about their age (Table 3).

When considering the structure of the sample according to the professional qualification, the same number of respondents (39.81\%) has graduated from a university and has completed high school. These categories make up the majority of respondents 
in the sample. Respondents with completed master studies, magisterium or doctorate make $19.16 \%$ of the sample. Less than $1 \%$ of the sample has completed elementary school only. Four respondents did not provide information on the qualifications (Table 3).

Finally, through the analysis of Table 3, it can be noted that most of the sample consists of respondents who live in the household with average monthly income, $48.90 \%$ of them. Respondents living in households below average monthly income make up 33.68\% of the sample (Table 3). The lowest percentage of respondents, $17.30 \%$, lives in households with monthly income above the average (Table 3). Two respondents did not answer the question about the monthly income of their households (Table 3).

The sampling method was the stratified sample. The total population from the territory of the former Yugoslavian republics is divided into strata, which are now independent countries: Serbia, Croatia, Bosnia and Herzegovina, Montenegro, Macedonia, and Slovenia. After that, simple random sample method was used for each stratum.

The total population from the territory of the former Yugoslavian republics is about 20 million people while the size of the sample analyzed is 1,550 respondents. The sample size is small but acceptable, having in mind that this sample mostly reflects demographic structure of the analyzed population (in all ex-Yugoslavian republics women are more numerous than men, most of population has graduated from a high school and then those with an university degree are following, most people live in household with average monthly income) (State Statistical Office of Macedonia, 2018; Institute for Statistics of Serbia, 2018; Statistical Office of the Slovenia, 2018; Statistical Office of the Montenegro, 2018; Croatian Bureau of Statistics, 2018; Federal Office of Statistics of Bosnia and Herzegovina, 2018). The sample size is small but acceptable regarding the nature of investigation, changes of population characteristics, changes of investigation object.

\section{Instrument}

For the purposes of this study, and following the example of previously conducted research (Roozen and Pelsmacker, 2000; Gilg et al., 2005; Sinha-Khetriwala etal., 2005; Kipperberg, 2007; Xu et al., 2014) an instrument - the questionnaire - was composed to test the difference between consumers' environmental management of waste in different former Yugoslavian republics. The items in the questionnaire were adapted to the national and the international environment of the countries in which the research was conducted.

The questionnaire is composed of three parts (see Appendix). The first part of the questionnaire is the respondents' consent for filling the questionnaire. Completing the questionnaire was anonymous. The second part of the questionnaire is based on the demographic characteristics of the respondents: state, gender, age, education and monthly household income. State, gender, education and household monthly income inquiries are of a closed type, while the question of the age of the respondents is of open type. In order to maximally adjust the questionnaire to cross-cultural research, it was necessary to standardize the data relating to monthly household income, given the fact that this data is differently shown in Statistical Yearbooks for the year 2018 of analyzed countries. Data on household income is reduced to a monthly level per household, because such type of data was found in most of the Statistical Yearbooks analyzed from former Yugoslavian republics. Questions related to monthly household income were set 
in the currency of the country in which the questionnaire was distributed, for easier understanding and answering questions. The third part of the questionnaire refers to consumers' environmental management of waste (Table 4). It has 7 items and every item connected to different group of waste (products): 1) food, 2) chemicals and pharmacy products, 3) clothing and footwear, 4) furniture, 5) electrical appliances, 6) means of transport, and 7) products of paper and cardboard (Table 5). Answers to the questionnaire were measured by Likert scale: 1-strongly disagree, 2-mostly disagree, 3undefined, 4-mostly agree, and 5- completely agree.

Table 4. Descriptive statistics of items in the total sample. (Source: authors' data)

\begin{tabular}{c|c|c|c}
\hline & Items & M & SD \\
\hline \multirow{4}{*}{$\begin{array}{c}\text { Consumers' } \\
\text { environmental } \\
\text { management of waste }\end{array}$} & When possible, I put my leftover food in compost & 3.23 & 1.39 \\
\cline { 2 - 4 } & I do not throw expired medication in waste & 3.04 & 1.50 \\
\cline { 2 - 4 } & I do not throw away old clothes but rather donate it & 4.42 & .91 \\
\cline { 2 - 4 } & I would leave an old sofa by the garbage container & 3.01 & 1.60 \\
\cline { 2 - 4 } & $\begin{array}{c}\text { I put old electric appliances in the garbage container } \\
\text { Parts of unusable bicycle, car and/or engine I would place } \\
\text { next to the garbage container }\end{array}$ & 2.33 & 1.41 \\
\cline { 2 - 4 } & I put old paper into a paper container & 3.64 & 1.50 \\
\hline
\end{tabular}

Table 5. Descriptive statistics of items regarding different groups of products and former Yugoslavian republics. (Source: authors' data)

\begin{tabular}{|c|c|c|c|c|c|c|c|c|c|c|c|c|}
\hline \multirow{2}{*}{$\begin{array}{l}\text { Country } \\
\text { Product } \\
\end{array}$} & \multicolumn{2}{|c|}{ 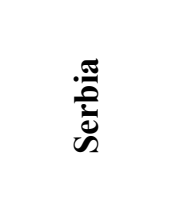 } & \multicolumn{2}{|c|}{ 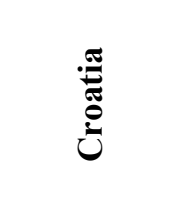 } & \multicolumn{2}{|c|}{ 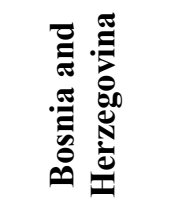 } & \multicolumn{2}{|c|}{ 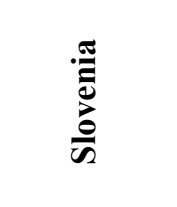 } & \multicolumn{2}{|c|}{ 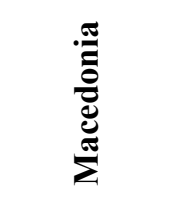 } & \multicolumn{2}{|c|}{ 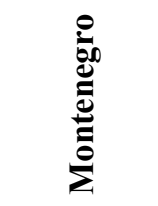 } \\
\hline & $M$ & SD & M & SD & $\mathrm{M}$ & SD & $M$ & SD & M & SD & M & SD \\
\hline Food & 3.0 & 1.36 & 3.3 & 1.42 & 3.0 & 1.40 & 4.3 & .940 & 2.7 & 1.28 & 3.0 & 1.34 \\
\hline Medicaments & 3.0 & 1.51 & 3.2 & 1.38 & 2.8 & 1.41 & 4.0 & 1.20 & 2.5 & 1.37 & 2.6 & 1.56 \\
\hline $\begin{array}{l}\text { Clothing and } \\
\text { footwear }\end{array}$ & 4.4 & .968 & 4.3 & .939 & 4.4 & .878 & 4.6 & .772 & 4.4 & .932 & 4.3 & .981 \\
\hline Furniture & 3.5 & 1.46 & 3.1 & 1.47 & 3.1 & 1.53 & 2.1 & 1.56 & 2.6 & 1.59 & 3.3 & 1.57 \\
\hline $\begin{array}{c}\text { Technical devices } \\
\text { (e-waste) }\end{array}$ & 2.6 & 1.46 & 2.3 & 1.29 & 2.4 & 1.30 & 1.5 & .975 & 2.2 & 1.44 & 2.7 & 1.54 \\
\hline $\begin{array}{l}\text { Means of } \\
\text { transport }\end{array}$ & 3.0 & 1.54 & 2.6 & 1.42 & 2.8 & 1.54 & 1.7 & 1.14 & 2.4 & 1.44 & 2.8 & 1.52 \\
\hline Paper & 3.4 & 1.43 & 4.1 & 1.17 & 3.4 & 1.42 & 4.8 & .504 & 3.2 & 1.40 & 2.8 & 1.51 \\
\hline
\end{tabular}

The questionnaires were translated into Slovenian, Macedonian, Croatian, and Serbian. Respondents from Serbia, Bosnia and Herzegovina, and Montenegro filled in questionnaires in Serbian considering that they can be classified in the same language area.

The questionnaire was distributed personally "paper and pencil" (PAPI - Paper and pencil interviewing) (Lavrakas, 2008) and through various Internet platforms (Google Drive, Facebook, email, etc.). It was given to the respondents by researchers, who had asked their colleagues, friends and family to fill the questionnaire and to send other 
copies to their friends and colleagues. Also, it was sent by the Internet to the e-mail addresses of various entities: private individuals, non-governmental organizations, higher education institutions, businesses, statistical bureaus of the countries, etc.

\section{Variables}

Independent variables in this study are: country, gender, age, professional qualification and monthly income by household, while the dependent variable is consumers' environmental management of waste.

\section{Data analysis}

For data processing, authors used the software package SPSS:16 (Norusis, 2008).

Preparing the data for the main analysis included the replacement of missing values by EM method and the treatment of extreme values that resulted in not showing even one outlier.

After preparing the data, exploratory factor analysis (EFA) was conducted. The results of EFA suggested that there is a relative satisfactory factor structure of the questionnaire. EFA was conducted for each country separately. Next, the obtained factor structure was confirmed by confirmatory factor analysis (CFA) in statistical packages "lavaan" and "semTools", written for the R environment.

One-way ANOVA with country as a factor (6 levels) and Tukey's HSD post hoc test were used as the methods for determining the differences in consumers' environmental management of waste between the former Yugoslavian republics. Also, two-way ANOVA and Tukey's HSD post hoc test were used to test the differences in demographic characteristics of respondents related to consumers' environmental management of waste between former Yugoslavian republics, with the following factors: country (6 levels) and gender (2 levels), country (6 levels) and age of respondents (6 levels), country (6 levels) and degree of education (4 levels), and country (6 levels) and monthly income by household (3 levels).

\section{Results}

\section{Descriptive statistics}

Descriptive statistics by arithmetic mean (M) and standard deviation (SD) of the questionnaire items regarding the consumers' environmental management of waste is shown in Table 4.

Table 5 shows descriptive statistics by arithmetic mean (M) and standard deviation (SD) of items regarding different groups of waste by products relative to former Yugoslavian republics.

Table 6 shows descriptive statistics for reliability of questionnaires by arithmetic mean (M) and standard deviation (SD). Results do not deviate significantly from the norm (the values of the skewness and kurtosis are within the allowed limits), despite the significant values of the K-S statistics (Kolmogorov-Smirnov test). Subscales reliability coefficients $(\alpha)$ for most of the individual countries are not proven to be quite adequate, since their values are lower than .70 (Table 6). The overall reliability coefficient for the sample is not entirely satisfactory since it is lower than the prescribed one. The reliability coefficient values could be explained by a small number of items for each subscale. The authors decided on a small number of items due to the nature of this cross-cultural study. 
Table 6. Descriptive statistics and reliability coefficients of questionnaire. (Source: authors' data)

\begin{tabular}{c|c|c|c|c|c|c}
\hline Country & M & SD & Skewness & Kurtosis & K-S & $\boldsymbol{\alpha}$ \\
\hline Serbia & 23.21 & 4.89 & -.319 & -.075 & $.070^{*}$ & .490 \\
Croatia & 22.99 & 5.27 & -.149 & -.543 & $.064^{*}$ & .660 \\
Bosnia and Herzegovina & 22.07 & 4.65 & -.118 & .001 & $.069^{*}$ & .440 \\
Montenegro & 21.74 & 5.09 & -.021 & .164 & $.076^{*}$ & .507 \\
Macedonia & 20.22 & 5.41 & .531 & .257 & $.089^{*}$ & .647 \\
Slovenia & 23.22 & 3.28 & .558 & .725 & $.210^{*}$ & .313 \\
Total & 22.26 & 4.92 & -.061 & -.037 & $.067^{*}$ & .483 \\
\hline
\end{tabular}

$* \mathrm{p}<.01$

\section{Differences in waste disposal among consumers from former Yugoslavian republics}

The results of the one-factor variance analysis with country as an independent variable (6 levels) and the dependent variable of consumers' environmental management of waste show that there is a statistically significant difference between the respondents from different countries in terms of consumers' environmental management of waste, $F(5,1544)=14.91, \mathrm{p}<.01, \eta_{\mathrm{p}}^{2}=.05$. Post hoc tests (Tukey's HSD) showed that respondents from Macedonia $(\mathrm{M}=20.22$, $\mathrm{SD}=5.42)$, dispose their waste in ecological way in the lowest degree in comparison to respondents from all other countries in the sample $(\mathrm{p}<.01)$. Also, it has been shown that respondents from Montenegro $(\mathrm{M}=21.74, \mathrm{SD}=5.1)$ disposed less of the waste in an ecological manner compared to respondents from Serbia $(M=23.21, S D=4.89, p<.01)$, Croatia $(M=23$, $\mathrm{SD}=5.27, \mathrm{p}<.01)$, and Slovenia $(\mathrm{M}=23.22, \mathrm{SD}=3.28, \mathrm{p}<.01)$.

The results of the one-factor analysis of the variance with the country as a factor ( 6 levels) and the consumers' environmental management of food waste as a dependent variable indicate that there are significant differences between respondents from different countries, $\mathrm{F}(5,1544)=48.02, \mathrm{p}<.01, \eta_{\mathrm{p}}^{2}=.14$. Post hoc tests show that respondents from Slovenia show a significantly higher level of ecological disposal of food waste, compared to respondents from all other countries $(p<.01)$. Respondents from Macedonia are less prone to dispose of food waste in ecological manner in comparison to respondents from Bosnia and Herzegovina and Croatia $(\mathrm{p}<.01)$.

The results of the one-factor analysis of variance with the country as a factor (6 levels) and the consumers" environmental management of medicament waste as a dependent variable indicate the existence of significant differences between respondents from different countries, $F(5,1544)=38.98, p<.01, \eta^{2} p=.11$. Post hoc tests $(p<.01-$ .05 ) suggest that respondents from Slovenia apply more ecological disposal of medicament waste in comparison to respondents from all other countries, and that respondents from Macedonia and Montenegro are less prone to ecological disposal of medication waste in comparison to respondents from Serbia and Croatia $(p<.01-.05)$.

The results of the one-factor variance analysis with the country as a factor (6 levels) and the consumers' environmental disposal of clothing and footwear waste as a dependent variable show that there are significant differences between the respondents, $\mathrm{F}(5,1544)=3.47, \mathrm{p}<.01, \eta_{\mathrm{p}}^{2}=.01$. Post hoc tests further show that respondents from Slovenia are ecologically disposing their clothing and footwear waste in a slightly higher degree, compared to respondents from Croatia and Montenegro $(p<.01-.05)$

The results of the one-factor analysis of variance with the country as a factor (6 levels) and the consumers' environmental disposal of furniture waste as a dependent 
variable show significant differences between respondents, $F(5,1544)=29.47, p<.01$, $\eta^{2}=.09$. Post hoc tests $(p<.01-.05)$ further demonstrated that respondents from Slovenia and Macedonia dispose of waste from furniture in an environmentally friendly manner to the lowest degree when compared to respondents from all other countries. Also, it has been shown that respondents from Serbia are using this behavior to a greater extent in comparison to respondents from Croatia and Bosnia and Herzegovina.

The results of the one-factor analysis of variance with the country as a factor (6 levels) and the consumers' environmental management of electronic waste as a dependent variable show that there are significant differences between the respondents, $\mathrm{F}(5,1544)=23.94, \mathrm{p}<.01, \eta_{\mathrm{p}}^{2}=.07$. Post hoc tests have shown $(\mathrm{p}<.01-.05)$ that respondents from Slovenia are more prone to ecological disposing of electrical waste compared to respondents from all other countries.

The results of the one-factor analysis of variance with the country as a factor (6 levels) and the consumers' environmental management of waste from means of transport as a dependent variable indicate that there are significant differences between the respondents, $F(5,1544)=28.78, p<.01, \eta_{p}^{2}=.09$. Post hoc tests $(p<.01-.05)$ indicate that respondents from Slovenia, again, are most prone to ecologically dispose their means of transport waste, compared to respondents from all other countries. On the other hand, respondents from Serbia are more environmentally irresponsible when it comes to the disposal of waste from means of transport, in comparison to respondents from Croatia and Macedonia.

The results of the one-factor analysis of variance with the country as a factor (6 levels) and the consumers' environmental management of paper waste as a dependent variable indicate that there are statistically significant differences between respondents from different countries, $F(5,1544)=77.01, p<.01, \eta^{2}=.20$. Post hoc tests $(p<.01)$ further demonstrated that respondents from Slovenia and Croatia to the greatest extent ecologically dispose their paper waste in comparison to respondents from all other countries. Also, it has been shown that the respondents from Montenegro are least prone to ecologically manage their paper waste in comparison to respondents from other countries $(\mathrm{p}<.01)$.

\section{Differences in demographic characteristics in relation to waste disposal in an environmentally friendly manner}

Gender - Disposal of waste in an environmentally friendly way: The results of a twofactor variance analysis with factors country (6 levels) and gender ( 2 levels) point to a statistically significant main effect of the sex, $\mathrm{F}(1,1537)=5.44, \mathrm{p}<.05,=.02 \eta p 2=$ .01 , and a statistically significant main effect of the country, $F(5,1537)=13.18, \mathrm{p}<$ $.01, \eta \mathrm{p} 2=.04$. Gender-to-country interaction is not statistically significant, $\mathrm{F}(5,1537)$ $=1.97$, ns. The results of post hoc tests (Tukey's HSD) indicate that female respondents $(\mathrm{M}=22.53, \mathrm{SD}=4.85)$ more dispose the waste in a way that does not degrade the environment, compared to male respondents $(\mathrm{M}=21.79, \mathrm{SD}=5.00)$ in all countries.

Age - Disposal of waste in an environmentally friendly way: The results of a twofactor analysis of variance with factor country (6 levels) and age ( 5 levels) point to a statistically significant main effect of age, $F(2,1537)=19.27, p<.01, .02=\eta p 2=.02$, statistically significant main effect of the country, $F(4,1510)=11.84, p<.01 \eta p 2=$ .02 , and statistically significant interaction between country and age, F $(22,1510)=$ $1.77, \mathrm{p}<.05, \eta \mathrm{p} 2=.02$. Post hock test (Tukey's HSD) indicates that the youngest respondents from Macedonia, aged 18-30 years $(M=19.14, S D=4.65 ; p<.01)$, are less prone to disposing the waste in an ecological manner polluting the waste in an 
environmentally-friendly manner than respondents from Croatia, aged 31-40 $(\mathrm{M}=$ 25.22, $\mathrm{SD}=4.86 ; \mathrm{p}<.01)$.

Education - Disposal of waste in an environmentally friendly way: The results of a two-factor analysis of variance with factors country (6 levels) and education level (4 levels) point to the statistically significant main effect of the country, $F(13,1524)=$ $10.92, \mathrm{p}<.01, \eta \mathrm{p} 2=.02$, that the main effect of the education level is not statistically significant, $\mathrm{F}(2,1524)=<1$, ns, and that the interaction between the country and the education level is statistically significant, $F(13,1524)=3.37, p<.01, \eta p 2=.02$. Post hoc test (Tukey's HSD) indicates that respondents from Macedonia with university degree $(M=19.43, S D=5.26)$ are less involved in the disposal of waste in such a way as not to degrade the environment than respondents from: a) Serbia with completed high school $(\mathrm{M}=23.37, \mathrm{SD}=4.99, \mathrm{p}<.01), \mathrm{b})$ Croatia with university education $(\mathrm{M}=$ 23.61, $\mathrm{SD}=5.01, \mathrm{p}<.01)$, and $\mathrm{c})$ Slovenia with a completed university education $(\mathrm{M}=$ 23.22, $\mathrm{SD}=3.01 ; \mathrm{p}<.01)$.

Monthly household income - Disposal of waste in an environmentally friendly way: The results of a two-factor variance analysis with factors country (6 levels) and monthly household income (3 levels) point to the statistically significant main effect of the country, $\mathrm{F}(5,1530)=8.99, \mathrm{p}<.01, \eta \mathrm{p} 2=.02$, that the main effect of monthly household income is not statistically significant, F $(2,1530)=1.63$, ns., and that the interaction between the state and monthly household income, $\mathrm{F}(10,1530)=2.02, \mathrm{p}<$ $.01, \eta \mathrm{p} 2=.01$., is statistically significant. Post hoc test (Tukey's HSD) indicates that respondents from Macedonia with above-average household income $(\mathrm{M}=19.53, \mathrm{SD}=$ 5.49) are less involved in waste disposal in a way that does not degrade the environment than respondents from: a) Serbia with above-average monthly household income $(\mathrm{M}=$ $22.71, \mathrm{SD}=5.08, \mathrm{p}<.01)$, with average monthly household income $(\mathrm{M}=24, \mathrm{SD})$, and with below-average monthly household income $(\mathrm{AS}=23.19, \mathrm{SD}=4.92, \mathrm{p}<=4.51, \mathrm{p}<$ $.01)$; b) Croatia with above-average monthly household income ( $\mathrm{AS}=24.92, \mathrm{SD}=5.04$, $\mathrm{p}<.01)$ and average monthly household income $(\mathrm{AS}=22.63, \mathrm{SD}=5.37, \mathrm{p}<.01), \mathrm{c})$ Slovenia with above-average monthly household income $(\mathrm{AS}=23.40, \mathrm{SD}=3.52, \mathrm{p}<$ $.01)$.

\section{Discussion}

The results show that there are differences in waste management in an environmentally friendly manner among consumers from different former Yugoslavian republics. The results obtained confirm the hypothesis $\mathrm{H} 0$ - there are differences in environmental management of waste between consumers from former Yugoslavian republics.

The results obtained confirm the differences between consumers' environmental management of waste in different countries, found in previously conducted crosscultural studies (Arbuthnot and Lingg, 1975; Roozen and Pelsmacker, 2000; SinhaKhetriwala et al., 2005; Kipperberg, 2007; Xu et al., 2014). The obtained results can be explained by the various macroeconomic factors mentioned in Table 1. Earlier studies confirm that different macroeconomic factors affect the diversity in the environmentally responsible behavior of consumers, which is the elimination of waste in an environmentally friendly manner (Dolan, 2002; Schaefer and Crane, 2005; Thøgersen, 2005; Assadourian, 2010; Marx et al., 2010). The results point that:

- Regarding the overall waste management in an environmentally friendly way (regardless of the type of waste), it can be concluded that the consumers from 
Macedonia have a lowest level of waste management in an environmentally friendly manner in comparison to all other countries in the sample. The above can be explained by the fact that Macedonia has the lowest value of the macroeconomic factor "Environmental sustainability" in comparison to all other former Yugoslavian republics (Table 1). Also, the "Environmental sustainability" factor has the decrease tendency for Macedonia only. Environmental sustainability is a factor that directly indicates the country's readiness to protect its environment, while managing waste in an ecologically friendly manner is the type of environmentally responsible consumer behavior that significantly depends on the government activity and the functionality of the waste management system at the state level.

- When consumers from Slovenia were analyzed, it was concluded that they are more ready than consumers from all other countries in the sample to environmentally manage different types of waste: food, medicaments, electrical appliances, means of transport and paper. This can be explained by the fact that Slovenia has the highest values for all of the macro factors analyzed in Table 1: GDP per capita, quality of education, sophisticated business and environmental sustainability, and each in its own way positively affects the environmental management of waste.

- Regarding the differences in the disposal of food waste in an environmentally friendly manner, the difference between the respondents from Macedonia and the respondents from Montenegro is evident, which can be explained by the fact that Montenegro has higher values for most of the factors analyzed in Table 1: GDP per capita, quality of education, and environmental sustainability.

- Respondents from Macedonia and Montenegro are less disposing of medical and chemical waste in an environmentally-friendly manner than respondents from Croatia, which can be explained by the fact that Macedonia and Montenegro in relation to Croatia have lower values for all mentioned macroeconomic factors from Table 1: GDP per capita, quality of education, sophisticated business and environmental sustainability.

- Respondents from Slovenia are more prone to disposing of clothing and footwear in an environmentally-friendly way than respondents from Croatia and Montenegro, which can also be explained by the fact that Slovenia in comparison to Croatia and Montenegro has higher values for all macroeconomic factors from Table 1: GDP per capita, quality of education, sophisticated business and environmental sustainability)

- If the disposal of furniture in an ecologically friendly way is analyzed, there are differences observed between Serbia on one side and Croatia and Bosnia and Herzegovina on the other side, where respondents from Serbia are more environmentally responsible when disposing of furniture waste than respondents from Croatia and Bosnia and Herzegovina, which can be explained by the fact that Serbia has the lowest value of the factor "Environmental footprint" (Table 1), which implies that Serbia is less prone to waste and degradation its natural resources for the better quality of life in relation to Croatia and Bosnia and Herzegovina. In other words, respondents from Serbia pollute less and less degrade the environment, among other things, with furniture waste. 
- Also, the observed differences in the disposal of furniture waste in an environmentally friendly manner are present between Slovenia and all other countries of the sample, in the sense that respondents from Slovenia are less likely to dispose of furniture waste in an environmentally friendly way than respondents from all other countries of the sample, which is explained by the fact that Slovenia has the highest value of the "Environmental footprint" factor (Table 1) than all other analyzed countries, which means that Slovenia mostly consumes and degrades its natural resources for a better standard of living, which includes furniture and waste disposal from it.

- Further, the observed differences between the disposal of waste in an environmentally friendly manner are such that respondents from Macedonia are less prone to dispose their furniture waste in an environmentally-friendly way than those from all other sample countries, which is explained by the lowest value of the macroeconomic factor "Environmental sustainability" in comparison with all other former Yugoslavian republics and the fact that this factor only in Macedonia has a decrease tendency in Macedonia only (Table 1).

- Respondents from Serbia are less able to dispose their transport vehicles and parts of transport vehicles in an environmentally-friendly manner than respondents from Croatia and Macedonia, which can be explained by the fact that Serbia has the lowest degree of macroeconomic factor "Sophistication of business", which also includes educational promotional campaigns on the importance of ecological manner of disposal of transportation means and their parts.

The obtained differences between countries that can not be explained by variations in macroeconomic factors (Table 1) can be explained by differences in the awareness, knowledge and attitude towards the environment in consumers from different analyzed countries (Arbuthnot and Lingg, 1975; Roozen and Pelsmacker, 2000; Sinha-Khetriwala et al., 2005; Kipperberg, 2007; Xu et al., 2014).

The obtained results indicate that there are no gender differences, while there are differences in age, education and monthly household income in relation to the disposal of waste in an environmentally friendly manner among consumers from the territory of the former Yugoslavia. The obtained results partially confirm the $\mathrm{H} 2$ hypothesis - there are demographic differences in the disposal of waste in a way that does not degrade the environment among consumers from the territory of the former Yugoslavia.

In all former Yugoslavian republics women environmentally dispose of waste more than men, which is also confirmed by previous research results conducted in: Singapore (Shamdasani et al., 1993), United Kingdom (Gilg et al., 2005), Greece (Tilikidou and Delistavrou, 2008; Abeliotis et al., 2010), Portugal (De Paço and Raposo, 2010; Paçoand Lavrador, 2017), Italy (Pedrini and Ferri, 2014; Talia et al., 2019), Germany (Scherer et al., 2018). Studies conducted in: United States of America (Granzin and Olsen, 1991; Savchenko et al., 2019), United Kingdom (Samdahl and Robertson, 1989; Gilg et al., 2005), China (Chan, 2001), Portugal (De Paço and Raposo, 2010), Italy (Talia et al., 2019), Germany (Pagiaslis and Krontalis, 2014), Spain (Pérez-Belis et al., 2017) and Denmark (Aschemann-Witzel et al., 2017) confirm that there are differences in consumers age related to their ecologically responsible waste disposal. Studies conducted in: United States of America (Arbuthnotand Lingg, 1975; Granzin and Olsen, 1991), United Kingdom (Samdahl and Robertson, 1989), China (Chan, 2001), India (Jain andKaur, 2006), Greece (Tilikidou and Delistavrou, 2008; Abeliotis et al., 2010), Portugal (De Paço and Raposo, 2010), Italy (Pedriniand Feri, 2014; Talia et al., 2019), 
Denmark (Aschemann-Witzel et al., 2017) and Germany (Pinto et al., 2014; Pagiaslis and Krontalis, 2014) confirm that there are differences in consumers' education level in comparison to environmentally responsible disposal of waste of consumers. That there are differences in certain countries regarding monthly household income in comparison to consumers' ecological waste disposal is confirmed by studies conducted in: United States of America (Granzin and Olsen, 1991), United Kingdom (Samdahl and Robertson, 1989), China (Chan, 2001; Zhang et al., 2018), India (Jain and Kaur, 2006), Greece (Tilikidou and Delistavrou, 2008; Abeliotis et al., 2010), Portugal (De Paço and Raposo, 2010), Italy (Pedrini and Feri, 2014; Talia et al., 2019) and Germany (Pinto et al., 2014; Pagiaslis and Krontalis, 2014) and Denmark (Aschemann-Witzel et al., 2017).

\section{Limitations of research}

Although this cross-cultural research was done with caution, it has certain limitations. The firstcan be that the questionnaire was designed for research purposes and it was not used elsewhere, and cannot be characterized as being of multiple uses. The second limitation can be the number of items in the questionnaire - seven. That is a small number of items, which is why maybe the structure of the questionnaire is not ideal. Consumers' environmental management of waste is a socially desirable behavior and it is assumed that respondents were subjective and that they were giving socially desirable answers, which is also considered a limitation of the study.

\section{Conclusion}

This is the first cross-cultural research of differences in environmental management of waste by consumers from the former Yugoslavian republics, and as such it provides valuable information.

The results indicate that there are differences in environmental management of waste between consumers from: Macedonia and all other former Yugoslavian republics, and from Montenegro in comparison to Serbia, Croatia and Slovenia. There are differences in consumers' environmental management of different types of waste: regarding food waste - between Slovenia and all other former Yugoslavian republics and Macedonia in comparison to Bosnia and Herzegovina and Croatia; regarding medicament waste between Slovenia and all other former Yugoslavian republics and between Macedonia and Montenegro in comparison to Croatia and Serbia; regarding clothing and footwear waste - between Slovenia on one hand and Croatia and Montenegro on the other hand; regarding furniture waste -between Slovenia and Macedonia in comparison to all other former Yugoslavian republics; regarding e-waste - between Slovenia and all other former Yugoslavian republics; regarding waste from means of transport - between Slovenia and all other former Yugoslavian republics and Serbia in comparison to Croatia and Macedonia; regarding paper waste - between Slovenia and Croatia in comparison to all other former Yugoslavian republics and between Montenegro and all other former Yugoslavian republics.

Differences in environmental waste recycling between countries can largely be explained by the macroeconomic factors, while part of the results can be explained by differences in consumer awareness, attitude and knowledge regarding environment.

Results indicate that there are no differences in gender but that there are differences in age, degree of education and monthly income by households related to environmental management of waste between consumers from former Yugoslavian republics. As for the age, differences were noted between the youngest respondents from Macedonia, 
aged 18 to 30, and respondents from Croatia aged from 31 to 40 years, in sense that respondents from Macedonia are less likely to dispose of waste in an ecological way than respondents from Croatia. Regarding the level of education, respondents from Macedonia with higher education are less involved in the disposal of waste in such a way that the environment is not degraded than the respondents from: a) Serbia with a completed high school, b) Croatia with a university degree, and c) Slovenia with completed university degree. When it comes to monthly household income, the results show that respondents from Macedonia with above-average household income are less involved in waste disposal in a way that does not degrade the environment than respondents from: a) Serbia with above-average monthly household income, with average monthly household income, and below-average monthly income; b) Croatia with above-average monthly household income, and with average monthly household income, c) Slovenia with above-average monthly household income.

The practical application of the results is reflected in the possibility of more efficient management of consumer waste in an environmentally friendly manner on the territory of former Yugoslavian republics and also globally. Therefore, the consumer behavior can become a tool of environmental management and improve the quality of life in the region. The results indicate that in the territory of the former Yugoslavian republics there are different segments of consumers regarding behavioral variable of consumers' ecological waste management. However, it is necessary to adapt consumer waste management strategies in an environmentally friendly way to different segments i. e. countries. The most resources should be invested in order to bring the consumer waste management strategy in an environmentally friendly manner "most intensively" for consumers in Macedonia and the least resources for a consumer waste management strategy in an environmentally friendly way are needed for consumers from Slovenia. Also, the results indicate that there are market segments if we look at consumer management of different types of waste in an environmentally friendly manner, such as food, medicaments, clothing and footwear, furniture, e-waste, means of transport, or paper. For example, when analyzing waste from furniture, consumers from Slovenia only in this type of waste are less environmentally conscious than consumers from other countries in the sample, which indicates that the waste management strategy for ecologically oriented consumers in Slovenia should be created in such a way that it contributes most to the disposal of furniture waste in an environmentally friendly way in comparison to other types of waste. Or, if consumers from Montenegro are observed, it is concluded that of all the countries in the sample they are the least prone to ecological managing of paper waste. It further implies that the environmental management strategy for consumers in Montenegro should be focused on the environmentally friendly disposal of paper waste in comparison to other types of waste. If we look at the results obtained by analyzing the differences in demographic characteristics with respect to the environmentally responsible disposal of waste, it is concluded that in all the countries of the former Yugoslavia, male part of population should be encourage more to disposed of waste in ecological terms, since in all countries it has been observed that women are more represented in this type of behavior. Also, the same segment of results indicates that consumers from Macedonia aged 18-30 years should be encouraged, as well as consumers from Macedonia who have completed university education and those from Macedonia with above-average monthly income, since it was observed that these demographic groups were least involved in the disposal of waste in an environmentally friendly manner. The obtained data can serve as a starting point for entering into horizontal and vertical partnerships between different entities on national and 
international levels, with the aim of protecting the environment through increased consumers' environmental management of waste.

From a theoretical perspective, the data obtained is important because it provides an empirical basis for other studies by creating an environmental profile of responsible consumers. Also, the research was conducted with a newly created questionnaire that can be used for other research, and for creating other questionnaires on the same topic.

It is also proposed to carry out research in the territory of former Yugoslavia republics in order to determine the correlation between macroeconomic factors and different types of ecologically responsible behavior of consumers, including disposal of waste in an environmentally friendly way, which would show whether and which - if any - macroeconomic factors influence different ecological responsible consumers' behavior. Finally, the authors suggest that more studies should be carried out on the topic of consumers' environmental management of waste, as this is the only way to analyze the limits and motivators of the environmentally responsible behavior of consumers.

\section{REFERENCES}

[1] Abeliotis, K., Koniari, C., Sardianou, E. (2010): The profile of the green consumer in Greece. - International Journal of Consumer Studies 34(2): 153-160.

[2] Arbuthnot, J., Lingg, S. (1975): A comparison of French and American environmental behaviors, knowledge and attitude. - International Journal of Psychology 10(4): 275-281.

[3] Aschemann-Witzel, J., Jensen, J. H., Jensen, M. H., Kulikovskaja, V. (2017): Consumer behaviour towards price-reduced suboptimal foods in the supermarket and the relation to food waste in households. - Appetite 116: 246-258.

[4] Assadourian, E. (2010): Transforming cultures: from consumerism to sustainability. Journal of Macromarketing 30(2): 186-191.

[5] Chan, R. Y. K. (2001): Environmental attitudes and behavior of consumers in China. Journal of International Consumer Marketing 11(4): 25-52.

[6] Croatian Bureau of Statistics (2018): Statistical Yearbook. - Croatian Bureau of Statistics. https://www.dzs.hr/Hrv_Eng/ljetopis/2018/sljh2018.pdf. Accessed on 02 February 2019.

[7] De Paço, A. M. F., Raposo, M. L. B. (2010): Green consumer market segmentation: empirical findings from Portugal. - International Journal of Consumer Studies 34(4): 429-436.

[8] Dolan, P. (2002): The sustainability of "sustainable consumption". - Journal of Macromarketing 22(2): 170-181.

[9] Federal Office of Statistics of Bosnia and Herzegovina (2018): Statistical Yearbook. Federal Office of Statistics of Bosnia and Herzegovina. https://docs.google.com/gview?url=http://fzs.ba/wpcontent/uploads/2019/01/Godisnjak2018.pdf. Accessed on 02 February 2019.

[10] Gilg, A., Barr, S., Ford, N. (2005): Green consumption or sustainable lifestyles? Identifying the sustainable consumer. - Futures 37(6): 481-504.

[11] Granzin, K. L., Olsen, J. E. (1991): Characterizing participants in activities protecting the environment: A focus on donating, recycling and conservation behaviors. - Journal of Public Policy and Marketing 10(2): 1-27.

[12] Institute for Statistics of Republic Serbia (2018): Statistical Yearbook. - Institute for Statistics of Republic Serbia. http://publikacije.stat.gov.rs/G2018/Pdf/G20182051.pdf. Accessed on 02 February 2019.

[13] Jain, S., Kaur, G. (2006): Role of socio-demographics in segmenting and profiling green consumers: an exploratory study of consumers in India. - Journal of International Consumer Marketing 18(3): 107-117. 
[14] Kipperberg, G (2007): A Comparison of household recycling behaviors in Norway and the United States. - Environmental and Resource Economics 36(2): 215-235.

[15] Lavrakas, P. J. (2008): Encyclopedia of Survey Research Methods. - Sage, Thousand Oaks, CA.

[16] Marx, A. M., De Paula, I. C., Sum, F. (2010): Sustainable consumption in Brazil: identification of preliminary requirements to guide product development and the definition of public policies. - Natural Resources Forum 34(1): 51-62.

[17] Norusis, M. (2008): SPSS 16.0 Advanced Statistical Procedures Companion. - Prentice Hall, Upper Saddle River, NJ.

[18] Pagiaslis, A., Krontalis, A. K. (2014): Green consumption behavior antecedents: environmental concern, knowledge, and beliefs. - Psychology and Marketing 31(5): 335348.

[19] Paço, A., Lavrador, T. (2017): Environmental knowledge and attitudes and behaviours towards energy consumption. - Journal of Environmental Management 197: 384-392.

[20] Pedrini, M., Ferri, L. M. (2014): Socio-demographic antecedents of responsible consumerism propensity. - International Journal of Consumer Studies 38(2): 127-138.

[21] Pérez-Belis, V., Braulio-Gonzalo, M., Juan, P., Bovea, D. M. (2017): Consumer attitude towards the repair and the second-hand purchase of small household electrical and electronic equipment. A Spanish case study. - Journal of Cleaner Production 158: 261275.

[22] Pinto, C. D., Herter, M. M., Rossi, P., Borges, A. (2014): Going green for self or for others? Gender and identity salience effects on sustainable consumption. - International Journal of Consumer Studies 38(5): 540-549.

[23] Raletić Jotanović, S., Milijanka, R., Zakić, N. (2017): Pro-environmental activities of consumers. - Polish Journal of Management Studies 16(1): 55-66.

[24] Raletić Jotanović, S., Sudarević, T., Katić, A., Kalinić, M., Kalinić, Č. (2016): Environmentally responsible purchasing. Analysis of the ex-Yugoslavian republics. Applied Ecology and Environmental Research 14(3): 559-572.

[25] Roozen, I. T. M., De Pelsmacker, P. (2000): Polish and Belgian consumers' perception of environmentally friendly behavior. - Journal of Consumer Studies and Home Economics 24(1): 9-21.

[26] Samdahl, D., Robertson, R. (1989): Social determinants of environmental concern: Specification and test of the model. - Environment and Behavior 21(1): 57-81.

[27] Savchenko, O., Kecinski, M., Li. T., Messer, K. (2019): Reclaimed water and food production: Cautionary tales from consumers research. - Environmental Research 120: 320-331.

[28] Schaefer, A., Crane, A. (2005): Addressing sustainability and consumption. - Journal of Macromarketing 25(1): 76-92.

[29] Scherer, C., Emberger-Klein, A., Menrad, K. (2018): Segmentation of interested and less interested consumers in sports equipment made of bio-based plastic. - Sustainable Production and Consumption 14: 53-65.

[30] Shamdasani, P., Chon-Lin, G. O., Richmond, D. (1993): Exploring green consumers in an oriental culture: role of personal and marketing mix factors. - Advances in Consumer Research 20(1): 488-493.

[31] Sinha-Khetriwala, D., Kraeuchi, P., Schwaninger, M. (2005): A comparison of electronic waste recycling in Switzerland and in India. - Environmental Impact Assessment Review 25(5): 492-504.

[32] State Statistical Office of the Macedonia (2018): Statistical Yearbook. - State Statistical Office of the Macedonia. http://www.stat.gov.mk/Publikacii/PDFSG2014/08PrihodiPotrosCeni-IncomeExpPrices.pdf. Accessed on 02 February 2019.

[33] Statistical Office of the Montenegro (2018): Statistical Yearbook. - Statistical Office of the Montenegro. - http://monstat.org/eng/publikacije_page.php?id=1518. Accessed on 02 February 2019. 
[34] Statistical Office of Slovenia (2018): Statistical Yearbook. - Statistical Office of Slovenia. https://www.stat.si/StatWeb/File/DocSysFile/10179/STATOBOOK_2018.pdf. Accessed on 02 February 2019.

[35] Talia, D. E., Simeone, M., Scarpato, D. (2019): Consumer behaviour types in household food waste. - Journal of Cleaner Production 214: 166-172.

[36] Thøgersen, J. (2005): How many consumer policy empower consumers for sustainable lifestyles? - Journal of Consumer Policy 28(2): 143-78.

[37] Tilikidou, I., Delistavrou, A. (2008): Types and influential factors of consumers' nonpurchasing ecological behaviors. - Business Strategy and the Environment 17(1): 61-76.

[38] WEF (2014): Global Competitiveness Report 2014-2015. - WEF, Geneva.

[39] WEF (2016-2017): Global Competitiveness Report 2016-2017. - WEF, Geneva.

[40] WEF (2018): Global Competitiveness Report 2018. - WEF, Geneva.

[41] Xu, Y., Chen, Y., Burman, R., Zhao, H. (2014): Second hand clothing consumption: a cross cultural comparison between American and Chinese young consumers. International Journal of Consumer Studies 38(6): 670-677.

[42] Zhang, H., Duan, H., Andric, J. M., Song, M., Yang, B. (2018): Characterization of household food waste and strategies for its reduction: a Shenzhen City case study. Waste Manag 78: 426-433.

\section{APPENDIX}

\section{Questionnaire used in this study}

Dear Sir/Madam,

Bearing in mind that this is one of rare cross cultural studies in our region, and that the results will provide valuable information on similarities and differences regarding our behavior as consumers, we kindly ask you to devote 10 minutes of your time, which will be enough to fill out this questionnaire.

This survey is entirely ANONYMOUS, which means that nobody will be able to associate you with your answers. Survey data will be processed in groups and will be used for scientific research purpose only.

We kindly ask you to answer ALL of the questions and check carefully whether you have completed the ENTIRE questionnaire.

You are free to send all of your questions and doubts relative to this research via e-mail: rsasaca@hotmail.com.

Filling out the questionnaire is voluntary and requires your consent. If you agree to participate in this survey, circle YES.

\section{AGREE TO PARTICIPATE IN THIS SURVEY:}

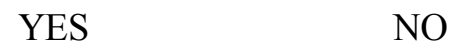

THANK YOU IN ADVANCE FOR YOUR COOPERATION!

Circle the number in front of the statement that applies to you.

Country:

1. Serbia 2. Croatia 3. Bosnia and Herzegovina 4. Slovenia 5. Macedonia

6. Monetenegro 
Gender:

1. male 2. female

Age (years)

Education:

1. elementary school 2. high school 3. University degree 4. MSc/Mr/Dr

The average monthly income per household in the Republic of Serbia, according to the Statistical Office, is 56,073.00 dinars for 2013. The total monthly income of your household is:

1. below average 2 . average 3 . above average

In the table below there are several statements describing different behaviors and attitudes which relate to ecological responsibility of consumers. Please, carefully read each of the statements and answer by circling the number and expressing to what degree you agree with each of the statements. Numbers have the following meaning:

1 - I strongly disagree, 2 - I disagree, 3 - Undecided, 4 - I agree, 5 - I strongly agree

\begin{tabular}{c|c|c}
\hline & Items & \\
\hline \multirow{4}{*}{$\begin{array}{c}\text { Environmental } \\
\text { management of waste }\end{array}$} & When possible, I put my leftover food in compost & 12345 \\
\cline { 2 - 3 } & I do not throw expired medication in waste & 12345 \\
\cline { 2 - 3 } & I do not throw away old clothes but rather donate it & 12345 \\
\cline { 2 - 3 } & I would leave an old sofa by the garbage container & 12345 \\
\cline { 2 - 3 } & $\begin{array}{c}\text { Parts of unusable bicycle, car and/or engine I would place } \\
\text { next to the garbage container }\end{array}$ & 12345 \\
\cline { 2 - 3 } & I put old paper into a paper container & 12345 \\
\hline
\end{tabular}

